Brazilian Journal of Political Economy, vol. 40, $n^{\circ}$ 2, pp. 285-309, April-June/2020

\title{
Profit margins, exchange rates and structural change: empirical evidences for the period 1996-20171
}

\author{
Margens de lucro, taxas de câmbio e mudança estrutural: \\ evidências empíricas para o período 1996-2017
}

\author{
NELSON MARCONI* \\ GUILHERME MAGACHO ${ }^{+},++$ \\ JOÃO GUILHERME R. MACHADO ${ }^{x}$ \\ RAFAEL DE AZEVEDO RAMIRES LEÃO ${ }^{x x}$
}

\begin{abstract}
RESUMO: A pesquisa busca entender a relação entre a taxa de lucro e a taxa de câmbio e como essa relação pode impactar a estrutura produtiva. Construímos um modelo teórico no qual a taxa de câmbio influencia a taxa de lucro e argumentamos que, embora taxas de câmbio valorizadas possam beneficiar setores com altos coeficientes de insumos importados no curto prazo, porque diminuem seus custos, afeta negativamente a demanda agregada e também a sua demanda específica, podendo reduzir, portanto, a taxa de lucro desses setores, a médio prazo. No caso brasileiro, esses setores são os manufatureiros de alto conteúdo tecnológico.
\end{abstract}

PALAVRAS-CHAVE: Margens de lucro, taxa de câmbio; investimento; Novo Desenvolvimentismo; desindustrialização, manufatura; mudança estrutural.

ABSTRACT: This research seeks to understand the relationship between the rate of profit and the exchange rate and how this relationship can impact the productive structure. We

\footnotetext{
${ }^{1}$ This study was partially financed by the Coordenação de Aperfeiçoamento de Pessoal de Nível Superior - Brasil (CAPES) - Finance Code 001, by FGV-EAESP Pesquisa and by the Fundação de Amparo à Pesquisa do Estado de S. Paulo (FAPESP) - grant 2019/01353-0.

* Assistant Professor at Escola de Administração de Empresas de São Paulo da Fundação Getulio Vargas - EAESP-FGV, São Paulo/SP, Brasil. E-mail: nelson.marconi@fgv.br. ORCID: https://orcid.org/0000-00021399-5305.

+ Visiting Professor at Universidade Federal do ABC - UFABC,Santo André/SP, Brasil. E-mail: Guilherme.magacho@gmail.com. Orcid: https://orcid.org/0000-0002-6208-8226.

${ }^{++}$Research Associate CCEPP/Cambridge and CND-FGV.

x PhD Candidate in Public Administration/Escola de Administração de Empresas de São Paulo da Fundação Getulio Vargas - EAESP-FGV, São Paulo/SP, Brasil. E-mail:jgrmachado@gmail.com. Orcid: https:// orcid.org/0000-0001-9627-9680.

xx PhD Candidate in Public Administration/ Escola de Administração de Empresas de São Paulo da Fundação Getulio Vargas - EAESP-FGV, São Paulo/SP, Brasil. E-mail: leaorarl@gmail.com. Orcid: org/0000-0003-0837-6099. Submitted: 25/July/2019; Approved: 1/August/2019.
} 
construct a theoretical model in which the exchange rate influences the rate of profit, and we argue that although an overvalued exchange rate could benefit sectors with high imported input coefficients in the short term because it reduces costs, it negatively impacts the demand for their products and also reduces the aggregatedemand; hence, an overvalued exchange rate could shrink the profit rate of these sectors in the medium term. In the Brazilian case, these sectors are the high technological-content manufacturing sectors.

KEYWORDS: Profit-Margins, Exchange Rate; Investment; New Developmentalism; Deindustrialization; Manufacturing; Structural Change.

JEL Classification: F41; F63; L16; O11; O14.

\section{INTRODUCTION}

Sectors with higher profit rates are better positioned to face profit-squeeze situations than sectors with lower margins. However, according to orthodox theory, profit rates across sectors tend to converge in the long run. In this article, we first argue and seek to demonstrate that the behavior of profit rates in Brazil are quite different from those predicted by orthodox economics, and sectors that have lower profit rates, especially in manufacturing, are the most sophisticated (i.e.,, the ones with the largest technological content).

According to the new developmentalism theory, in the presence of Dutch Disease, manufacturing and tradable services require a higher equilibrium exchange rate to be competitive with the external firms since these sectors do not have the same comparative advantages as natural resource-based sectors. Moreover, since manufacturing and tradable services have lower profit margins than commodities (for the same reason) and non-tradeable sectors (for the lack of competition), the exchange rate variations can strictly influence their profit rates and investment decisions. Hence, we are trying to define a theoretical model to understand the relationship among the profit rate, the exchange rate and production structure, as the investment decision will seek the more profitable sectors.

Although the new developmentalism theory argues that the appreciation of the exchange rate reduces the profit margin, data show that this relationship may not occur in this direction in Brazil in the analyzed period. One possible explanation is the reaction of the entrepreneurs in relation to the chronic process of exchange rate appreciation. We suggested that they increase the imported inputs share in the production process to avoid decreasing profit rates, which was not followed by an export share increase in production and was also due to the currency appreciation; this mix deepened the deindustrialization process of the Brazilian economy. Therefore, the relationship between profit rates and exchange rates would not be clear in the short term but in the medium term, and it would contribute to the deindustrialization process in Brazil. We evaluate this hypothesis in this article after estimating the results of profit margins for the Brazilian economy since the 1990s for some sectors and the 2000s for others.

The first section presents a literature review of the relationship between the 
profit rate and the exchange rate. The second section, we provide our theoretical model of this relationship and describe the role of imported inputs and export coefficients in the profit rate determination. The third section, we present profit margins in Brazil and their relationship with the exchange rate, while in the forth section 4, we show the evolution of the input-output coefficients of imported and exported inputs and their relationship with the chronic appreciation of the Brazilian currency and the Brazilian deindustrialization, which we named "the trap strategy". Then, our concluding remarks are presented.

\section{THE RELATIONSHIP BETWEEN PROFIT AND EXCHANGE RATES: A THEORETICAL AND EMPIRICAL REVIEW}

According to a wide range of literature, the devaluation of the exchange rate exerts a positive effect on growth and economic development, as argued by Ferrari, Freitas \& Barbosa-Filho (2013), Guzman, Ocampo \& Stiglitz (2018), Rapetti (2016) and Rodrik (2008). These authors emphasize the role of the exchange rate level on the expansion of exports and investments, but they do not explore the channels that may lead to such results. Therefore, in this article, we explore these channels from the perspective of the new developmentalism theory, arguing that the exchange rate is relevant to grant access to domestic and external demand by means of its impact on profit rates and, consequently, on investments.

The exchange rate is one of the most important macroeconomic prices to New Developmentalism - along with profit, inflation, interest and wage rates - and one of the least studied prices (Bresser-Pereira, Marconi \& Oreiro, 2016, pp. 7, 51). According to the new developmentalism theory, the exchange rate is an important variable in profit rate determination; therefore, it is also important to determine the level of investments in a country and, as a consequence, to set the pace of their structural change and process of economic development (Bresser-Pereira, 2012, pp. 183-184; Bresser-Pereira et al., 2016, pp. 22, 41, 178). Empirical evidence connecting exchange rate devaluations, investments and growth can also be observed (Dao, Minoiu \& Ostry, 2017). Previous theories, such as the Neoclassical theory, Keynesian theory, and even the Structuralist theory, did not assign a relevant role for the exchange rate in the explanation of the behavior of profit rates since they assume that exchange rates fluctuate around the equilibrium level and that the deviations from that level are temporary. In this context, the exchange rate fluctuations are not relevant to determine profits and investments since their equilibrium level prevails. However, the new developmentalism theory argues that the exchange rate could be quite volatile and remain for prolonged periods of time at a lower level than necessary for the current account equilibrium (Bresser-Pereira, 2012, p. 189). If the exchange rate would be more volatile and the currency would appreciate for long periods, the entrepreneurs would assign greater weight to this variable in their investment decisions since it would affect the profit rate not only in the short term but for a period long enough to damage their accumulation. Consequently, the 
chronic process of exchange rate appreciation, when observed, creates relevant demand constraints to growth since this appreciation inhibits reaching a satisfactory profit rate even if the entrepreneur is efficient; in this situation, the firm is not able to compete in both the domestic and global markets. In this sense, the exchange rate becomes central in a world of globalized markets because its level determines the access to demand by the companies of a certain country for both the external market and its own domestic market (Bresser-Pereira, 2012, p. 182; Bresser-Pereira et al., 2016, pp. 41, 48, 52).

Given that the entrepreneurs have as their main incentive to earn profits, the investment rate, in turn, will depend on lucrative opportunities to access demand (for empirical evidence regarding profitability and investments see Basu \& Das, 2017). There is still a need for the exchange rate to remain predictable for a sufficiently long period for investments to take place and the profit rate to remain relatively stable over a period of time to compensate investment efforts, which may be hampered by volatility, besides the existence of appreciation tendencies of the exchange rate over time (Bresser-Pereira et al., 2016, pp. 113-123). In this sense, this research is interested in a deeper understanding of the relationship between profit rates and the exchange rate; this work also aims to show the dynamics of profit rates in Brazil between 1996 and 2017 and how these rates affected the productive structure.

Initially, it is necessary to step back and look for some studies that can help us to explain the relationship among profit rates, investments and exchange rates aside from the new developmentalism theory. In this article, we follow the traditional assumption that "desired accumulation positively depends on the profit rate" and that the current profit rate generates internal funding for capital accumulation, as it makes it easier for firms to access external funding (Lima, 2013, p. 347).

Barbosa et al. (2011, p. 6) argue that the price of tradable goods is a positive function of the domestic price of imports, and the price of non-tradable goods is defined based on a mark-up on production costs. Given the wage rate and input coefficients, the mark-up and prices of tradable goods are functions of the real exchange rate, so currency depreciations would enlarge the income profit share. Bhalla (2012) argues that current depreciations impact investments through the reduction of the international cost of production and the consequent increase in profitability for entrepreneurs who compare inversion opportunities all over the world. Blecker (2012) develops a model in which it is assumed that the firm's target mark-up rate is an increasing function of the real exchange rate because depreciation reduces the competition with external firms in the domestic market. Rapetti (2016) also defines an equilibrium exchange rate that allows the labor-intensive tradable sector in developing countries to reach a rate of profit at least equal to the ones obtained by similar firms in developed countries.

The discussion about the relationship between profit rates and exchange rates can also be found in empirical studies. As profit rates are sometimes difficult to calculate at the industry level because there are no sectorial capital stock measure- 
ments, many studies use profit margins as a proxy to it. ${ }^{2}$ Studying that relationship has become an important issue along with the introduction of global value chains and to understand profit rate adjustments in the developing economies. Mann (1986) observed how the exchange rate pass-through affects import and export prices in the US for several individual industries and how foreigners' suppliers' profit margins are squeezed by dollar fluctuations. The evidence found by Mann (1986) suggests that the profit margins of American export industries fluctuated much less than the margin of foreign suppliers that has absorbed exchange rate changes, a behavior in line with "theoretical models of imperfect competition and macroeconomic uncertainty" (Mann, 1986, p. 378). Therefore, exchange rate fluctuations may not be an issue for US manufacturing exports since the American currency is the typical currency in global trade, as it is for US foreigners' suppliers; as a consequence, these suppliers can experience profit squeezes during a dollar depreciation.

Klitgaard (1999) was interested in observing Japanese exporters' responses to maintain stable profit margins and sales volume along with Yen fluctuations, because they conflict due to price elasticity of demand. Furthermore, Klitgaard (1999, p. 41) finds that Japanese firms make a composition between these two goals, passing on part of the appreciation of the Yen to its external prices and partly reducing its profit margin according to how price is seen by US consumers. Hence, the author concludes that such adjustment "makes profit margins an important channel through which the exchange rate affects the Japan's economy" as argued by the new developmentalism theory.

Another well-known study about this issue was provided by Requena-Silvente \& Walker (2007), which investigated the impact of exchange rate movements over the UK car market's profit margins. In their study, the authors find that "manufacturers have implemented a 'pricing-to-market' strategy that leads exporters to reduce (or increase) profit rates for foreign cars whose currencies have appreciated (or depreciated) against the UK currency" (Requena-Silvente \& Walker, 2007, p. 216). In addition, in their findings, the exchange rate pass-through is diverse across countries: importers show asymmetric price-to-market behaviors, with mark-ups changing in a more pronounced manner with currency appreciations than depreciations, and local producers are sensitive to exchange rate fluctuations as they try to stabilize local currency prices.

For the Brazilian economy, the econometric study conducted by Feijo \& Cerqueira (2013) assessed the determinants of the mark-up of industrial firms during the 1990s, exploring a wide range of macroeconomic and microeconomic variables. Among those variables tested, the real effective exchange rate (REER) presented a positive relation with mark-up. The research argues that when the REER increased, the domestic protection degree in relation to imports increased, resulting in a mark-

\footnotetext{
2 Profit rates are measured by the division between total profits and capital stock, and profit margins are measured by the division between total profits and revenues, which is a proxy for the mark-up.
} 
up increase; they explain the positive relationship between profit margins and the exchange rate by changes in the degree of monopoly.

Some theoretical and empirical studies have emphasized the existence of a positive relationship between profits (margin or rate) and the exchange rate. This research advances this debate to analyze this argument, suggesting a theoretical model to more deeply understand this issue and provide empirical evidence about the arguments, as introduced in the next section.

\section{PROFIT RATES AND EXCHANGE RATES: THE BASIC MODEL}

To understand the relationship between profit margins and exchange rates, we built a mode ${ }^{3}$ that considers three different cost components-labor, domestic and imported inputs—and two sources of revenue for the firms-domestic and foreign sales. In this model, inventories are equal to zero; that is, the production is totally sold, which can be true after a few periods of adjustment in the production. The producer tries to maintain a certain profit rate level that is necessary to provide accumulation and to stimulate the continuous investment. If the manufacturer is a price-maker, this goal is easier to achieve; otherwise, he or she must look more closely to his cost structure. The exchange rate affects the profit rate insofar as it changes the cost on imported inputs, the constraints to fix prices in domestic and external markets and the export revenues (converted to local currency). The capitallabor ratio is considered fixed to simplify our explanation: ${ }^{4}$

$$
\pi=1-\left[\frac{U L C+\alpha \cdot P_{i m p} \cdot E+(1-\alpha) \cdot P_{n a c}}{\beta \cdot P_{\text {int }}+(1-\beta) \cdot P_{\text {exp }} \cdot E}\right] \cdot \frac{Y}{K}
$$

where

$$
\begin{aligned}
& K=\text { Capital Stock } \\
& \pi=\text { Profit rate } \\
& P_{\text {nac }}=\text { Domestic Input price } \\
& P_{\text {imp }}=\text { Imported Input price (in US } \$ \text { ) } \\
& P_{\text {int }}=\text { Price of Final Goods in Domestic Market } \\
& P_{\text {exp }}=\text { Price of Final Goods in Foreign Market (in US\$) } \\
& E=\text { Nominal exchange rate } \\
& Y=\text { Gross Output } \\
& \alpha=\text { imported inputs coefficient } \\
& 1-\alpha=\text { domestic inputs coefficient } \\
& \beta=\text { domestic revenues coefficient } \\
& 1-\beta=\text { exports coefficient }
\end{aligned}
$$

\footnotetext{
${ }^{3}$ See Appendix A.

${ }^{4}$ This model is representative of the firm behavior, so it is necessary to consider these three costs components and not only labor and imported inputs, which is the usual supposition for aggregated models.
} 
There is a large range of possibilities for trying to maintain a relatively stable and desirable profit rate over time. As we argued, if the producer is a price-maker, it is easier to react against cost inflation; however, if he is a price-taker, the constraints are larger, and it is necessary to manage costs more closely. Some of the strategies that producers can adopt, if they cannot raise prices to compensate for higher costs, are: a) when unit labor costs or the price of domestic inputs increase, the producer can replace both by imported inputs, which contributes to deindustrialization if the larger imported input coefficients (imported inputs/gross output) in many sectors are not followed by an increase in the export coefficients (exports/ gross output) in the same or other sectors; b) he can also try to increase labor productivity, which reduces unit labor costs (trying to raise capital productivity $\left(\frac{Y}{K}\right)$ is more difficult in the short term).

In turn, when the exchange rate depreciates, the producer increases the export revenues (quoted in domestic currency) and replaces more expensive imported inputs (also quoted in domestic currency) with labor or domestic inputs if the exchange rate pass-through to inflation is not high; as a result, the profit margin and the profit rate (if the capital productivity remains stable) can increase; the producer can also reduce the price of goods (quoted in foreign currency) and increase his revenue if the external demand for the good is elastic. This is the expected influence of a moderate exchange rate depreciation on profit rates according to the new developmentalism theory and other studies previously quoted. ${ }^{5}$ If the exchange rate appreciates, we expect the opposite effect in the export revenues, and the constraints to increase domestic price become larger (or the producers may even need decrease prices in domestic markets); both effects reduce the profit margins and rates. Therefore, we could argue that profit rates and exchange rates will vary in the same direction.

If the sector faces a high profit rate, the appreciation would reduce it but the its level would stay satisfactory to stimulate investments; but, in sectors with tighter profit rates, the chronic appreciation will lead the producer to reduce investments or even leave its business. In economies that have comparative advantages in primary sectors, the profit rate seems to be smaller inhigh-technology content sectors; therefore, an appreciation can move the production structure towards sectors with lower-technological content in the medium and long term, which means deindustrialization. ${ }^{6}$

However, there is another possible strategy that can avoid the fall in profit rates even when the process of chronic appreciation is present: the producers can

\footnotetext{
${ }^{5}$ Certainly, the depreciation cannot be large enough to pressure inflation. If the observed pass-through between the exchange rate and domestic prices is large, due, for example, to a relevant inertial component of wages and other costs, the constraints to devaluate the exchange rate are broader.

${ }^{6}$ In a sample of 43 countries, based on WIOD Database available for the period 2000-2014 (Timmer et al., 2015), 20 countries presented a higher average profit margin (estimated by the capital compensation/gross output ratio) between 2000 and 2014 for the commodities sector than for other manufactured goods producers.
} 
substitute labor and domestic inputs with imported inputs (which, in this situation, are cheaper when quoted in domestic currency) to reduce costs, as was pointed out by Montiel and Agenor (2008). This strategy can sustain a relatively stable profit rate but also implies in a deindustrialization process that negatively impacts the demand for domestic inputs and labor. In the long term, the profit rate will decrease due to the consequent reduction in aggregate demand. The difference, in this situation, is that it takes longer to reduce the profit rate, but the deindustrialization can be even more severe since the supply chains will disintegrate more intensely.

Hence, whether in the short or long term, the profit rates tend to follow the tendency of the exchange rate behavior; however, in the scenario of chronic appreciation, the deindustrialization seems to be larger. This is the argument that sustains the relevance of the maintenance of a competitive real exchange rate to improve the investment and the productive sophistication, mainly in countries with comparative advantages in natural resources. To check for these arguments, we provide some empirical evidence about the behavior of the profit margins and exchange rates in Brazil for the period of 1996-2017 in the next section.

\section{PROFIT MARGINS AND EXCHANGE RATES IN BRAZIL}

We built some series, which are as large as possible, to show the evolution of profit margins and profit rates in Brazil from the 1990s to the recent years and to compare them with the evolution of the real effective exchange rate. Data used to calculate the profit margins were extracted from the Annual Survey of Manufacturing (Instituto Brasileiro de Geografia e Estatística, 2019a), the Annual Survey of Services (Instituto Brasileiro de Geografia e Estatística, 2019b), the Annual Survey of Construction Industry (Instituto Brasileiro de Geografia e Estatística, 2019c) and the Annual Survey of Commerce (Instituto Brasileiro de Geografia e Estatística, 2019d) from the Brazilian Institute of Geography and Statistics (IBGE). ${ }^{7}$ Profit margins for the following periods were estimated given the availability of data: Manufacturing, 1996-2017; Services, 1998-2017 (except for 2002); Construction, 2002-2017; and Commerce, 2003-2017. We also used data from the Penn World Table version 9.1 (Feenstra, Inklaar \& Timmer, 2015) to calculate capital productivity and, hence, the rate of profit; data about profit margins, capital productivity, profit rates and real exchange rates are presented as three-year moving averages

\footnotetext{
7 Apart from the Annual Survey of Industry, which covers only companies with 5 or more employees, the other surveys cover all the companies in their respective sectors, with the exception of the following subsectors of services, which cover only the companies with 20 or more employees due to the lack of data: "Legal and accounting activities, activities of head offices, management consultancy activities"; "Architectural and engineering activities, technical testing and analysis"; "advertising and market research" and "other professional, scientific and technical activities, veterinary activities". Anyway, the profit margins for the aggregate services sector refer to all companies.
} 
since the profit margins are volatile, and we assume that the impact of the exchange rate variations on profit margins and rates are not immediate. ${ }^{8}$

Graph 1 compares the aggregate profit margin for the sectors included in the existing annual surveys - that is, for the sum of results for Mining and Quarrying, Manufacturing, Commerce, Services and Construction between 2005 and 2017 since it was not possible to aggregate sectorial data before that period due to small methodological differences in the surveys. There are two clear patterns throughout this period: between 2005 and 2011, the profit margins are relatively stable, and from 2012 to 2017, the profit margins have been consistently decreasing. We note three patterns for the real exchange rate: a strong appreciation between 2005 and 2011, a depreciation between 2011 and 2015 and a period of slight stability after 2016 (remembering that the moving averages are smoothing the evolution of both series). ${ }^{9}$

Graph 1: Profit Margin and Real Exchange Rate

(Manufacturing, Commerce, Services and Construction)

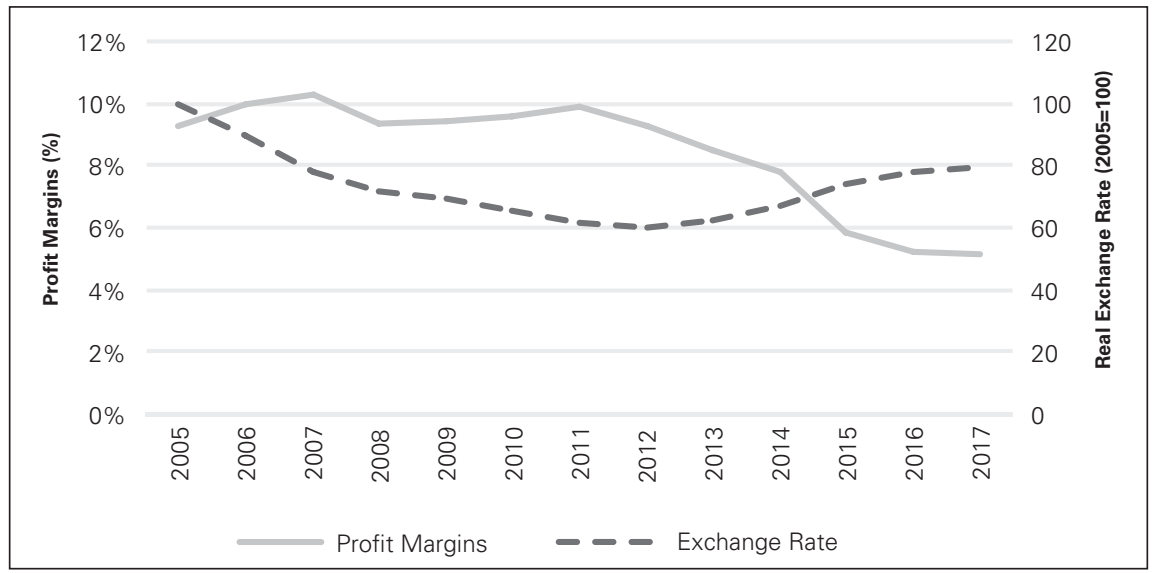

Source: Authors' estimation.

The evolution of the average profit rate in the Brazilian economy (estimated based on aggregated data including all that sectors - manufacturing, commerce,

\footnotetext{
${ }^{8}$ The definitions presented in the previous section were used to estimate profit margins and profit rates. Total revenues are equal to net sales + other operational revenues + non-operational revenues. The different subsectors in each of the surveys are categorized based on the Brazilian National Classification of Economic Activities (CNAE 1.0 and 2.0). To make these values compatible with the data of the Input-Output Matrix from WIOD (World Input-Output Database), which was used to estimate trade coefficients, we aggregated them based on the classification of the International Standard Industrial Classification (ISIC), revision 4. Due to the data available in The Penn World Tables, it is only possible to calculate the capital productivity for the economy as a whole; therefore, the profit rate cannot be calculated for the different ISIC 4 categories as is made possible for the profit margins.

${ }^{9}$ The real effective exchange rate estimated by IPEA was adopted, whose weights are based on 23 Brazilian trade partners for exports, and the deflators are consumer price indexes. The detailed methodology for the estimation can be found at ipeadata.gov.br.
} 
services and construction - multiplied by the capital productivity of the whole economy), included in Graph 2, exhibits a continuous tendency to decrease during the period observed. Despite two short periods of slight increasing profit margins, the profit rate has been constantly decreasing after 2007, as the capital productivity has been gradually decreasing year after year between 2005 and 2017. According to the theory, it is expected that somewhere along this period, the profit rate would have fallen below the "satisfying level" for the private sector, with expected deleterious consequences to the level of investments.

Graph 2: Capital Productivity,

Profit Margin and Profit Rate $(2005=100)$

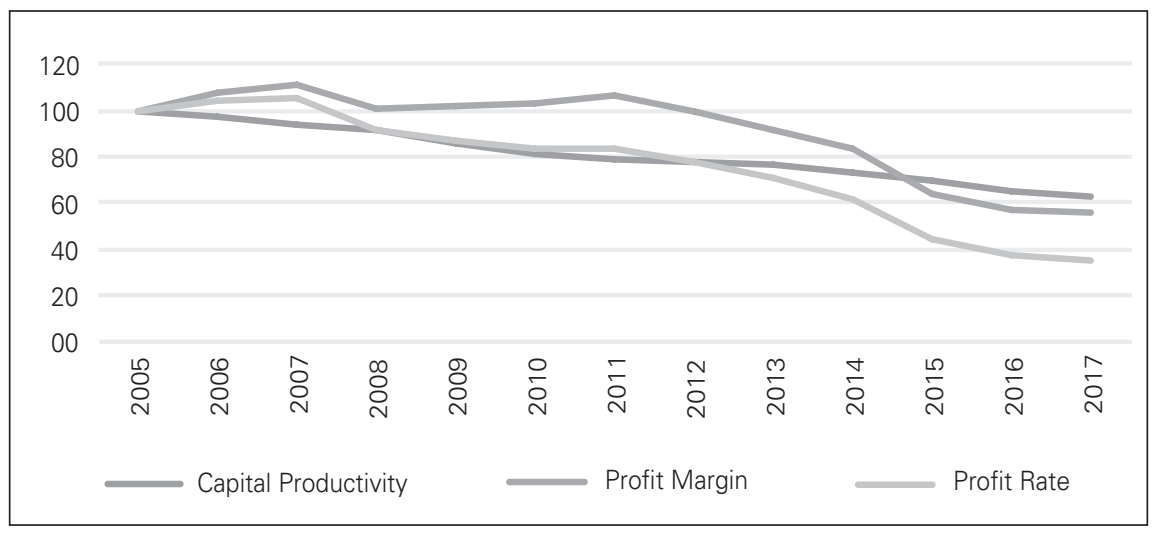

Source: Authors' estimation.

Therefore, considering both profit margins or rates in the analysis, the comparison between them and the real exchange rate does not present a similar behavior in this period, as expected at first sight. The relationship between the profit margins and the exchange rate in the Brazilian economy in the recent past is not so clear in the short term.

In search for checking the behavior of this relationship, we also analyze sectorial profit margins for Mining, Quarrying and Oil, ${ }^{10}$ Manufacturing, Commerce, Services and Construction. Observing Graph 3, it is evident that there are no signs of convergence of the profit margins among the different sectors; they vary considerably and distinctly across time, and profit margin levels are also distinct.

Construction and Mining, Quarrying and Oil have, most of the time, presented considerably higher margins than the other sectors. However, the latter is more volatile and was hit much harder by the recent crisis. Its profit margins plummeted from $26.1 \%$ in 2011 to $-5.7 \%$ in 2017 , being negative from 2015 onwards.

\footnotetext{
${ }^{10}$ This sector includes "Mining and Quarrying" and also "Manufacture of coke and refined petroleum products" which technically belongs to the manufacturing category, but it has a very close connection with quarrying.
} 
Construction profit margins have also fallen considerably when compared with the other 3 sectors. Services presents an "intermediate" level of profit margins, and it is also less volatile than Construction and Mining, Quarrying and Oil. Finally, Commerce and Manufacturing have much lower profit margin levels, most of the time, than the other sectors, rarely surpassing 7\%. Most of the years, Manufacturing posted profit margins lower than $5 \%$.

In general, the different sectors showed a fairly long period of gradual improvement of profit marginsduring the first period of exchange rate depreciation in the graph (between 1998 and 2004). There was a decrease of profit margins that started startedin different years after 2010 for the sectors included in the graphic. As a broad tendency, the profit rates declined at some point in 2010s and the real exchange rate started a second period of depreciation in 2012.

Graph 3: Profit Margins and Real Exchange Rate

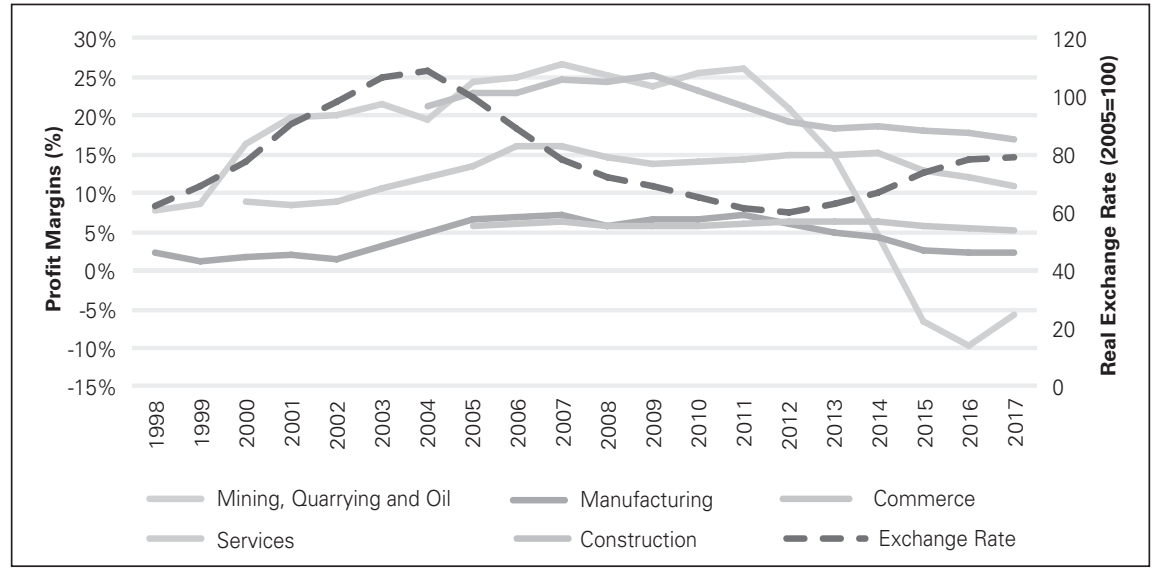

Source: Authors' estimation.

We disaggregated manufacturing according to the level of embodied technology since the subsectors, due to this characteristic, can be diversely affected by changes in the real exchange rate. It is possible that sectors that have higher technological content are more integrated into the global value chains, so they would suffer a distinct influence of exchange rate variations, in line with the arguments put forward by Patel et al. (2014), as well as they can be price-makers because they are better able to differentiate their products.

We can compare the results for both groups of sectors in Graphs 4 and 5. In fact, the profit margins of the different subsectors of Manufacturing show different levels and evolutions. In most cases, the subsectors considered as Medium-Low Technology (such as food products, beverages, and textiles) have slightly higher margins than subsectors considered as High and Medium-High Technology (such as computers, electronics, machinery, equipment and vehicles), which we have previously assumed as a feature of economies with large comparative advantages in natural resources 
such as Brazil. As we observed in the analysis for the whole manufacturing sector, the relationship between the profit margins in both groups of sectors and the exchange rate is not linear and positive during the observed period.

Graph 4: Profit Margins - Manufacturing - Medium-Low Technology - Selected Sectors

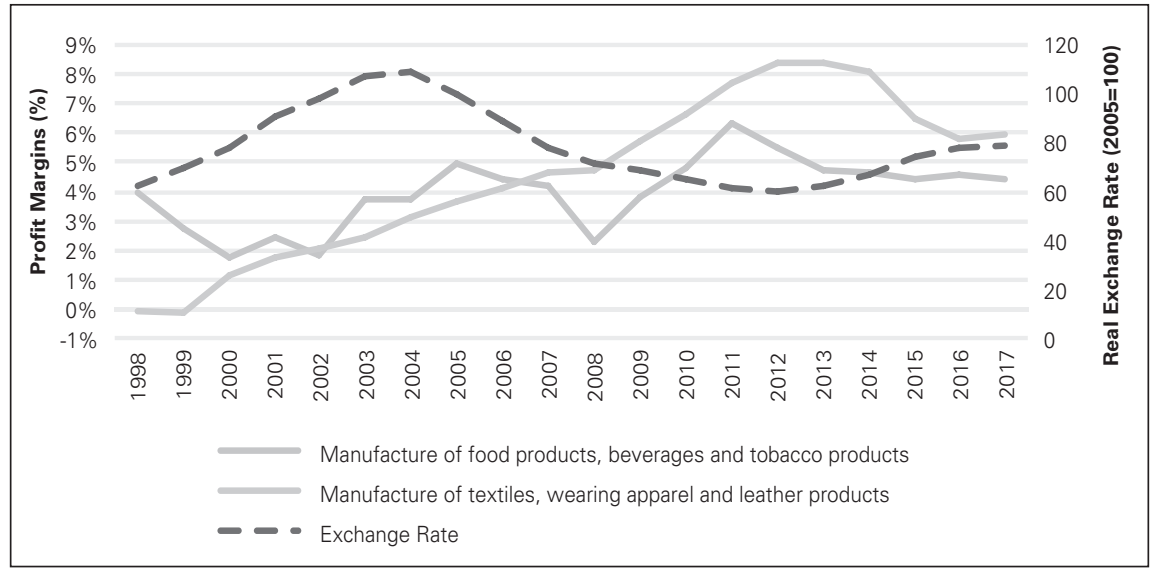

Source: Authors' estimation.

Graph 5: Profit Margins - Manufacturing - High and Medium High Technology - Selected Sectors

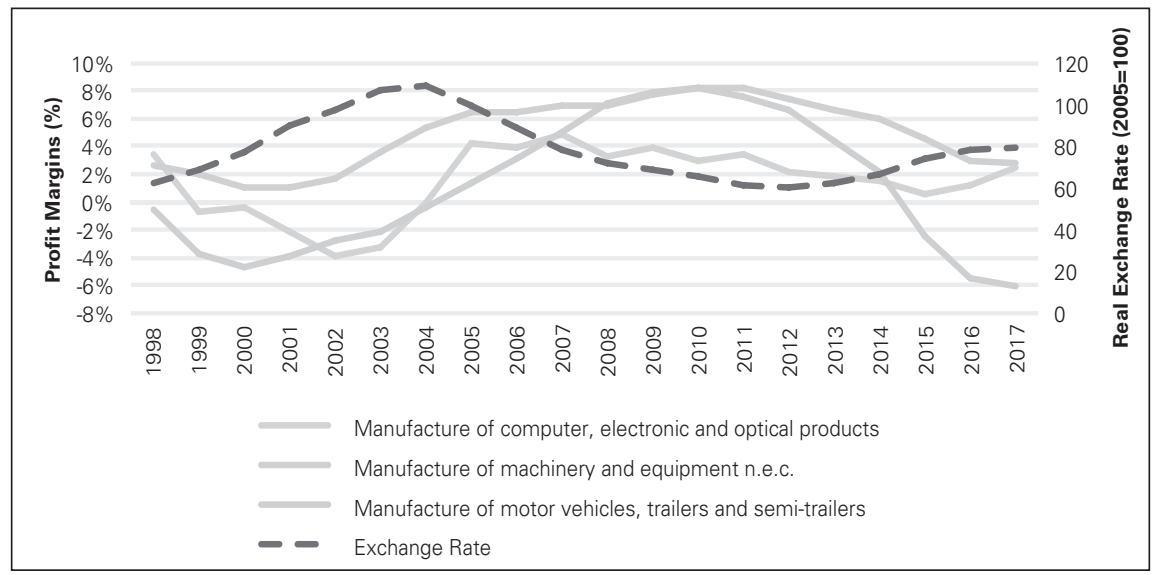

Source: Authors' estimation.

Since there are some services that can be considered tradables (we call them "modern"), the behavior of their profit margins is also shown in Graph 6. Modern Services sectors, in general, have higher margins than Manufacturing and appear to be less volatile and vulnerable to the effects of the recent economic crisis. As in the Manufacturing sector, the different subsectors of Services present distinct levels of profit margins, and there are no signs of convergence among them. With the 
exception of "Computer programming and consultancy activities" for the period between 2005 and 2010, there is also no clear and positive relationship between profit margins and real exchange rate.

Graph 6: Profit Margins - Modern Services - Selected Sectors

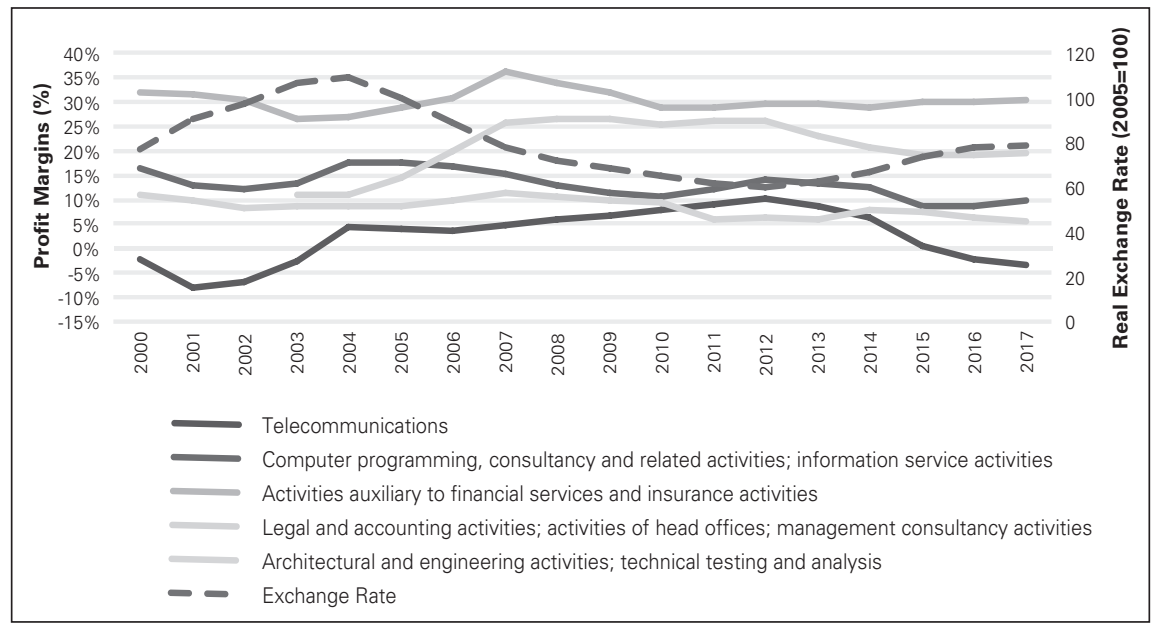

Source: Authors' estimation.

To summarize, we can stress three points. First, the sectors have different "levels" of profit margins, and there are no signs of convergence; second, the sectors tend to react differently to the economy's fluctuation and crisis, both in terms of timing of the reversion of trends and in terms of degree of its volatility; finally, the relationship between the exchange rate and profit margins, at least for the analyzed sectors and the period considered, is not linear nor directly correlated, indicating that it is more complex than assumed.

To try to explain the relationship between profit rates and exchange rates, it is possible to argue that the depreciation after 2011 was not sufficient to revert the misalignment of the exchange rate and the effects of the long appreciation period of 2000s. In fact, it is observed in Graph 7 that the real exchange rate remained appreciated between 2006 and 2018 (with the exception of 2015). ${ }^{11}$

In the previous section, we discuss some strategies that entrepreneurs can adopt to respond to the chronic appreciation of a currency and to try to maintain the profit margins to be relatively stable. One of those strategies is the substitution of local with imported inputs. In the next section, we analyze this option in the Brazilian economy, which we named "trap strategy", due to its impacts on aggregate demand and the production structure of an economy.

\footnotetext{
11 The misalignment is estimated as the difference between the indexes of real effective and industrial equilibrium exchange rates. The methodology for the estimation of the index of industrial equilibrium exchange rate follows Marconi (2012), and it can be found in the details at https://cnd.fgv.br.
} 
Graph 7: Exchange rate misalignment in the Brazilian economy based

on the comparison between the index of industrial equilibrium real effective exchange rate (IEER) and the index of observed real effective exchange rate (REER)

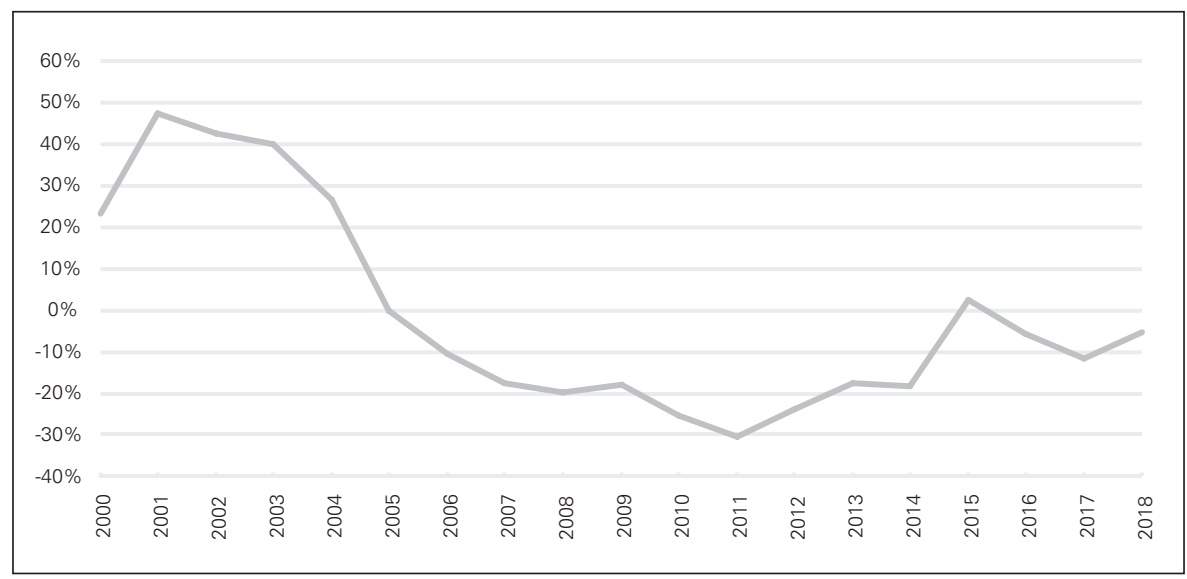

Source: Authors' estimation.

\section{THE TRAP STRATEGY}

A relevant part of the demand for manufacturing goods comes from manufacturing itself as an intermediate input. In almost every country, the process of industrialization was a process of increasing domestic linkages among sectors. The higher those linkages are, the higher are the impacts on employment and demand on other sectors (Hirschman, 1958, 1968) and consequently on total demand as well.

Nevertheless, the increasing participation of countries in global value chains (GVC) has been changing the rationale behind this process. Due to the reduction of transportation costs, the increasing facility of communication boosted by the ICT revolution and the countries' reduction of import barriers, goods are increasingly being produced through fragmented processes in which each country contributes in different stages of value chains (Gereffi, 1994). On the one hand, these changes in production processes make it possible for low and middle-income countries to have access to technologies that would be inaccessible if they were producing as isolated as before. On the other hand, they are increasingly forced to specialize in processes they have local comparative advantages, which tend to be less complex, as they do not have all capabilities the high-income countries have. Therefore, the developing countries that succeed in this context are those capable of producing in the most complex stages - those stages that generate higher technological spillovers and more qualified jobs (Gereffi, Humphrey \& Sturgeon, 2005).

Despite being a good opportunity for developing nations, Brazil does not seem to be one of the countries taking advantage of this new context. Brazilian manufacturing has decreased its share of GDP in the last decades, both in terms of value added and employment, as observed in Table 1 . 
Table 1

\begin{tabular}{|c|c|c|c|}
\hline Manufacturing & 1995 & 2018 & Var \% \\
\hline$\%$ share in Value Added ${ }^{12}$ & 16.0 & 11.3 & $-29.4 \%$ \\
\hline$\%$ share in Employment ${ }^{13}$ & 13.0 & 10.6 & $-18.5 \%$ \\
\hline
\end{tabular}

Source: Authors' estimation. ${ }^{1213}$

Therefore, it makes sense to investigate Brazil's insertion in the global value chains. To examine this process, we took advantage of data of the World OutputInput Database (WIOD) available for the period 2000-2014 (Timmer et al., 2015). Based on the WIOD, we calculated two coefficients for all the sectors with data availability using the classification put forth by the International Standard Industrial Classification (ISIC), revision 4.

The first coefficient is the share of imported inputs as a percentage of total production ("imported inputs coefficient"). Therefore, a higher share of imported inputs means that the sector relies heavily on imported inputs to the detriment of inputs produced domestically. The second coefficient is the share of exports as a percentage of total production ("exports coefficient"). It shows the percentage of domestic output that is exported to foreign countries.

To present how those coefficients evolved, we focus on data in 2000 and 2014, the first and the last years available on the WIOD, respectively. In general terms, data for 2000, included in Graph 8, show that the different sectors have very different imported input coefficients and export coefficients. For instance, the imported inputs coefficient varies between $7.4 \%$ for pharmaceutical products and up to $32.2 \%$ in computer and electronics. The export coefficient increases from $1.0 \%$ for printing and media to $34.3 \%$ for other transport equipment. In addition, half the sectors have higher export coefficients than imported input coefficients, though most of those sectors have low levels of sophistication.

Data for 2014, in Graph 9, show a very different picture. As in 2000, sectors continue to have distinct imported input coefficients and export coefficients. However, there are only four sectors with higher export coefficients than imported input coefficients. In addition, more than half of the sectors have imported input coefficients higher than $15 \%$, while in 2000 , that happened only for four sectors.

Therefore, it is crystal clear that between 2000 and 2014, there was a huge spike of imported inputs vis-à-vis exports. This phenomenon is better illustrated by Graphs 10 and 11, in which the sectors are disaggregated according to their levels of sophistication.

\footnotetext{
12 Estimation based on data from National Accounts, at the constant prices of 2018.

${ }^{13}$ Data from National Accounts. For 2017 and 2018, the estimations are based on the variation of employment in manufacturing between 2016 and 2018 from PNAD (National Household Sample Survey), IBGE.
} 
Graph 8: Imported inputs and exports (\% of output), Brazil, 2000

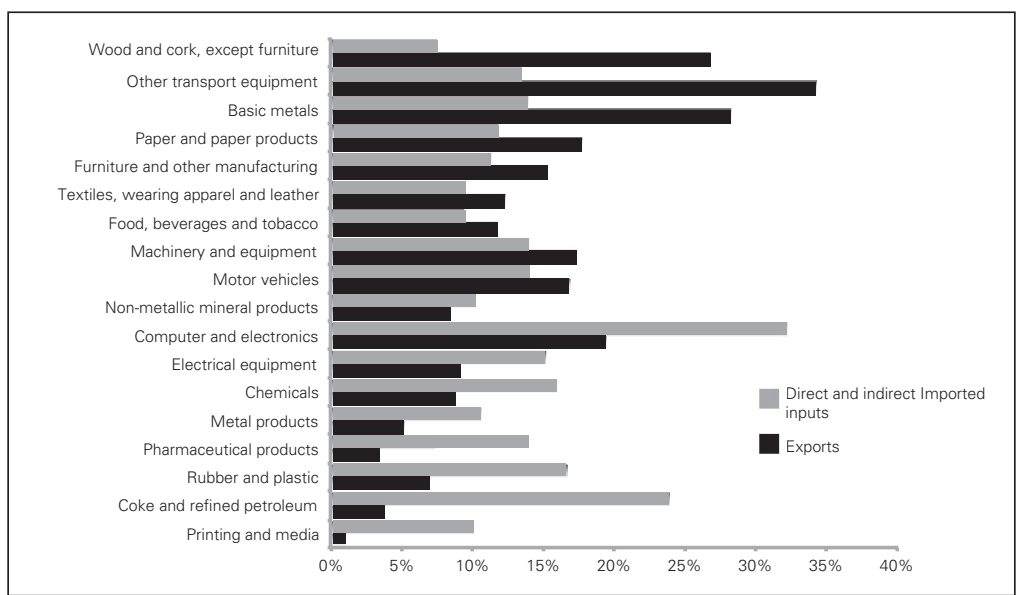

Source: Authors' estimation.

Graph 9: Imported inputs and exports (\% of output), Brazil, 2014

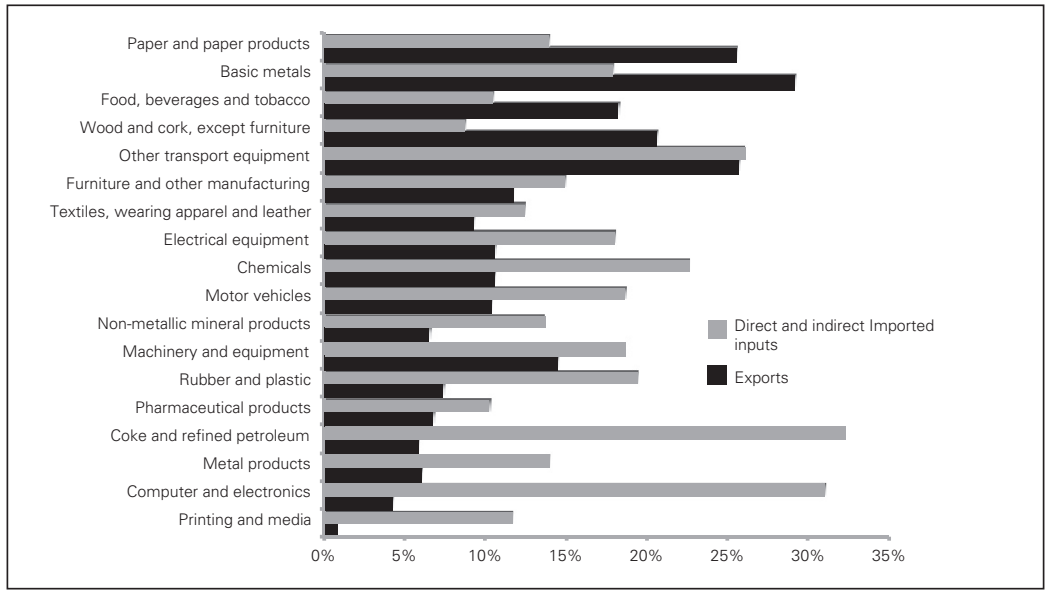

Source: Authors' estimation.

Graph 10 presents data for low and medium technology sectors for 2000 and 2014. There was an increase of the imported input coefficients in every sector (all arrows are pointing right). In half the sectors, there was also an increase in the export coefficients (with arrows pointing up). However, only two sectors (Food and beverages and Paper products) posted a higher increase of the export coefficients than imported input coefficients, benefiting the most of this process. Despite this fact, there are four sectors that were on the higher part of the graph (above the dashed line) both in 2000 and 2014, meaning that they have higher export coefficients than imported input coefficients. 
Graph 10: Imported inputs and exports (\% of output), Brazil, 2000-2014, low and medium tech industries

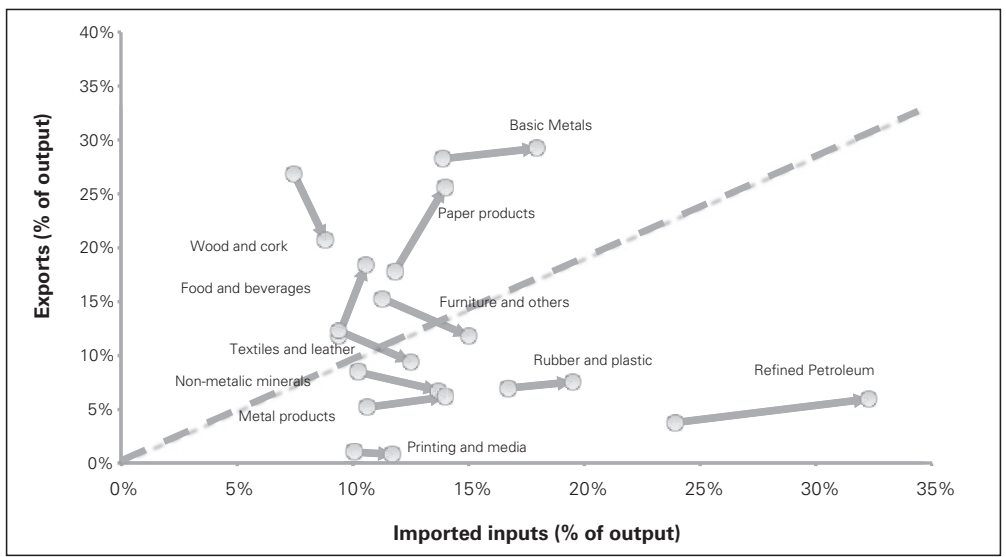

Source: Authors' estimation.

Graph 11 presents the coefficients for the medium high and high-tech sectors for 2000 and 2014. Almost every sector showed an increase in the imported inputs coefficient (except for Computer and electronics, which posted a very small decrease, but its exports coefficient plummeted; coincidentally, this sector exhibits a similar tendency for profit rates and exchange rates between 2005 and 2010, as we have observed in the analysis of data included in Graph 6). Most of the sectors also showed a decrease in the export coefficients. Even those sectors with an increase in the export coefficients showed an even higher increase in the imported input coefficients (except for pharmaceutical products). Finally, in 2000 there were three sectors with higher export coefficients than imported input coefficients (above

Graph 11: Imported inputs and exports (\% of output), Brazil, 2000-2014, medium-high and high tech industries

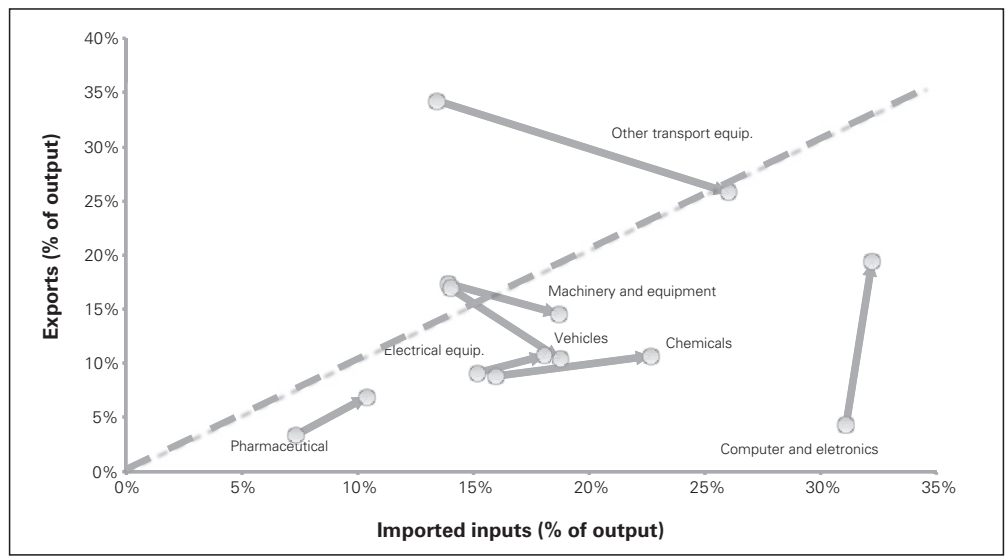

Source: Authors' estimation. 
the dashed line): Other transport equipment, Machinery and Equipment, and Vehicles. In 2014, all sectors posted higher imported input coefficients than export coefficients, including the three sectors mentioned above.

Overall, the data presented show a spike in imported inputs that is not fully compensated by an increase in exports, especially in medium-high and high technology sectors. Companies are increasingly turning to imported inputs to the detriment of domestic inputs. Therefore, we can argue that there are increasing leakages in productive chains in almost every sector.

It would be expected that a country whose participation in GVC is positive, in terms of economic development, would have its exports of sophisticated goods increased to compensate for an increase in imported inputs, especially those with high value added (Gereffi \& Sturgeon, 2013). In Brazil, precisely the opposite has been taking place. The sectors with higher export coefficients than imported input coefficients are low and medium technology industries (mostly natural resourcebased) and all medium-high and high technology sectors have higher imported input coefficients than export coefficients. In addition, Brazil has been consistently importing more inputs into every sector and reducing its exports as a percentage of production in half of the sectors. Even in the sectors with increasing export coefficients, only in a handful of low and medium technology industries was the increase high enough to compensate for the also increasing imported input coefficients.

Therefore, broadly speaking, even though Brazilian production has been changing to a more globalized framework, the quality of Brazil's insertion in the global value chains is very low and has been alarmingly deteriorating in the later years.

Among other factors, the long period of real appreciation of the Brazilian currency seems to be determinant for such an increase in imported input coefficients and a reduction of export coefficients in the medium-high and high-tech industries. As discussed in the previous section, it is possible that, after long periods of highly appreciated currency, producers react against this process by increasing the imported inputs coefficient and reducing the exports coefficient (even though the opposite seems to be not true - long periods of depreciation does not automatically reduce the imported input coefficients).

Graph 12 presents the difference between the industrial equilibrium and the actual real effective exchange rate indexes for the Brazilian economy between 2000 and 2014, as well as the ratio between the export and imported input coefficients. The difference among those indexes is the misalignment presented in Graph 7. From 2005 onwards the real exchange rate was overvalued compared to the industrial equilibrium exchange rate. Not coincidently, from 2005 and 2011 the exports to imported inputs ratio had decreased significantly - in the low and medium tech industries it decreased from 1.48 to 0.90 , while in the medium-high and high-tech industries it decreased from 1.02 to 0.65 . 
Graph 12: Industrial equilibium and real exchange rate, 12 months average, (2005=100), left axis and export and imported inputs coefficients ratio, right axis

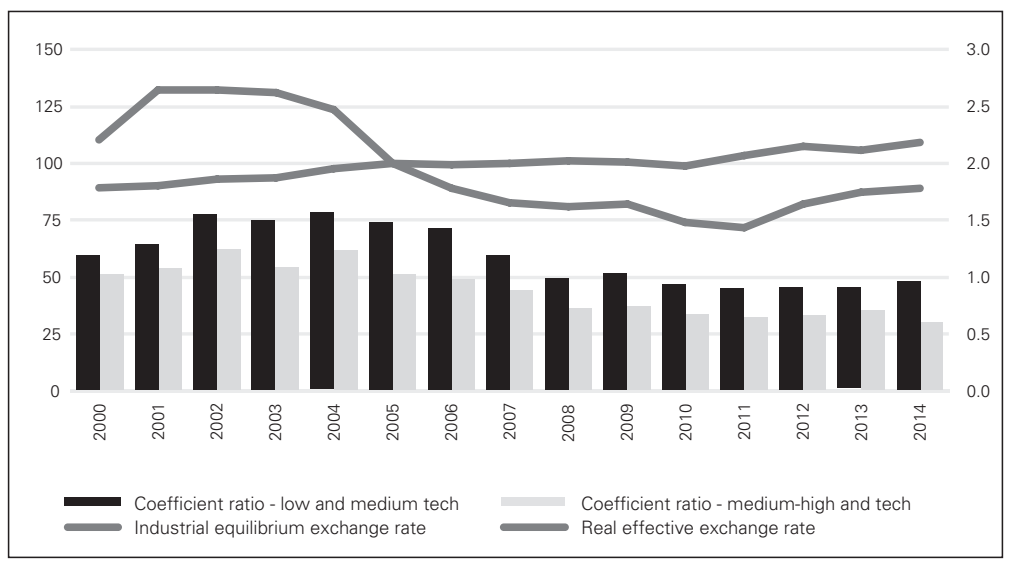

Source: Authors' estimation.

Substituting domestic inputs for imported inputs is a rational strategy for domestic firms when the real exchange rate is appreciated. By doing this, firms reduce costs and, with some degree of monopoly in the domestic market, their profit margins are not constrained. Even though this substitution benefits firms from a microeconomic perspective (at least in the short term), the macroeconomic result is not as good as the result for the firms individually. The substitution of domestic inputs by imported inputs not compensated by an increase in exports has created a trap for the economy as a whole in the medium term.

Graph 13: Current Account Deficit and

Manufacturing Trade Balance vs. Financial Account

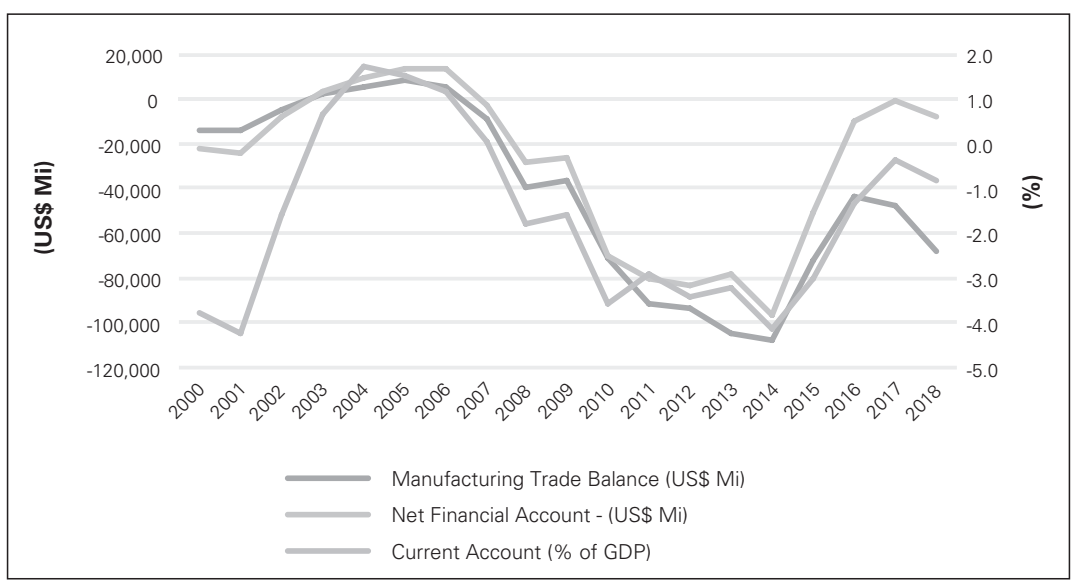

Source: Net Financial Account: Net Concessions (-) Net Funds; BCB/Funcex - Authors' elaboration. 
The manufacturing deficit has increased from 2005 to 2014 since manufacturing imports (mainly inputs) were growing much faster than its exports. ${ }^{14}$ During the period of a high increase of commodities demand and prices led by the Chinese Miracle in the 2000s, the current account deficit was relatively stable. However, the deacceleration of China and other Asian countries' demand for such products reduced the speed of price growth. This phenomenon brought another issue: balance of payments became sustainable only due to increasing capital inflows. Thereby, the high (and increasing) necessity of external financing turned into an external sector crisis. The continuity of this self-destroying process was impossible, and its collapse was only a matter of time. In 2015, after a (not surprising) decrease in commodities prices, the capital inflows plummeted, and the model that worked for many years became unsustainable, because producers, by adopting this strategy, preserved their profit margins in the short term but became more vulnerable to external shocks; thus, producers contributed to the reduction of interindustry demand and to the weakening of the supply chains and the proper aggregate demand in the medium term, which negatively impacted the profit margins. A famous Brazilian song from the 1990s used to say that "não era amor, era cilada" (it was not love, it was a trap). In this case, we could say "it was not development, it was a trap". Therefore, the exchange rate appreciation, which does not seem to be relevant to determine the profit margins in the short term, possibly contributes to reducing profit margins and to the regression of the production structure in the medium and long term because the profit margins are lower in sectors with higher technological content in the Brazilian economy, as we observed in the previous sections.

\section{CONCLUDING REMARKS}

Following many years of exchange rate misalignments, the structure of trade for Brazilian firms has been modified, especially in high-tech industries. Exports now represent a relatively low share of total output, while imported inputs are a much more relevant part of total costs. What will these firms demand from the government in terms of commercial polices? What will be the desired exchange rate for these producers? For industrial firms that export little and import much, overvalued exchange rates are preferable: they reduce the firms' costs and allow them to compete with foreign firms in the domestic market (at least in the short term) since they have not had access to external demand for some years. In the same vein, unilateral tariff cuts are demanded by these agents since they will also reduce their costs.

Reversing this scenario, therefore, requires an additional effort put toward macroeconomic and industrial policy, as maintaining the exchange rate at a competitive level, although essential for the economic development, would increase the

\footnotetext{
${ }^{14}$ Intermediate inputs correspond to $52 \%$ of the import increase between 2005 and 2014; capital goods correspond to $13 \%$ and durable goods for $6 \%$ only.
} 
costs after an accommodation of enterprises to the effects of a long period of accentuated exchange rate overvaluation. It is not possible to neglect that commercial openness is necessary. Brazilian tariffs are higher than those of most developing countries. Nevertheless, such openness must be structured to promote exports, with special regards to high-tech exports. Tariff cuts may reduce production costs, but they will increase imports. Thereby, it is necessary to implement a trade openness in parallel with many other competitive polices. Investments in infrastructure (physical and technological) and in research and development, as well as in promoting a structural transformation towards a green economy, are essential to guarantee an adequate insertion of the Brazilian industry into the global value chains. Moreover, although quality is gaining momentum in international trade, price competitiveness is still relevant. Hence, the macroeconomic policy should avoid the overvaluation of the exchange rate; one of the targets for this policy should be the maintenance of the exchange rate at the industrial equilibrium level, which can guarantee, given other characteristics of the economy, that the efficient manufacturing producers would get to compete in domestic and external markets; i.e.,, they would be able to reach profit rates similar to those of their competitors in domestic and foreign markets.

\section{REFERENCES}

Barbosa Filho, N., Silva, J. A., Goto, F., \& Silva, B. (2011). Crescimento econômico, acumulação de capital e taxa de câmbio. Taxa de câmbio no Brasil: estudos de uma perspectiva do desenvolvimento econômico. São Paulo: Elsevier.

Basu, D., \& Das, D. (2017). Profitability and Investment: Evidence from India's Organized Manufacturing Sector. Metroeconomica, 68(1), 47-90.

Bhalla, S. S. (2012). Devaluing to prosperity: misaligned currencies and their growth consequence. Peterson Institute.

Blecker, R. A. (2011). Open economy models of distribution and growth. Hein, E. and Stockhammer, E. (eds.), A modern guide to Keynesian macroeconomics and economic policies, 215-39.

Bresser-Pereira, L. C. (2012). A taxa de câmbio no centro da teoria do desenvolvimento. Estudos Avançados, 26(75 SE-Novo Desenvolvimento). Retrieved from https://www.revistas.usp.br/eav/article/ view/39481.

Bresser-Pereira, L. C., Marconi, N., \& Oreiro, J. L. (2016). Macroeconomia desenvolvimentista: teoria e politica econômica do novo desenvolvimentismo. São Paulo: Elsevier

Dao, M. C., Minoiu, M. C., \& Ostry, M. J. D. (2017). Corporate Investment and the Real Exchange Rate. International Monetary Fund.

Feijo, C. A., \& Cerqueira, L. F. (2013). Econometric evidence on the determinants of the mark up of industrial Brazilian firms in the 1990s. Revista Economia, 14(1).

Feenstra, R. C., Inklaar, R. and Timmer M. P.. (2015), "The Next Generation of the Penn World Table" American Economic Review, 105(10), 3150-3182, available for download at www.ggdc.net/pwt

Ferrari, M. A. R., Freitas, F. N. P., \& Barbosa-Filho, N. (2013). A taxa de câmbio real e a restrição externa: uma proposta de releitura com elasticidades endógenas. Revista de Economia Política, $33(1), 60-81$.

Gereffi, G. (1994) The organization of buyer-driven global commodity chains: how U.S. retailers shape overseas production networks. In: GEREFFI, G.; KORZENIEWICZ, M. (Eds.). Commodity chains and global capitalism. Westport: Greenwood Press. p. 95-122. 
Gereffi, G.; Humphrey, J.; Sturgeon, T. (2005) The governance of global value chains. Review of International Political Economy, v. 12, n. 1, p. 78-104,.

Gereffi, G.; Sturgeon, T. (2013). Global value chains and industrial policy: the role of emerging economies. In: ELMES, D.; LOW, P. (Eds.). Global value chains in a changing world. Geneva: WTO,.

Guzman, M., Ocampo, J. A., \& Stiglitz, J. E. (2018). Real exchange rate policies for economic development. World Development, 110, 51-62. https://doi.org/10.1016/j.worlddev.2018.05.017

Hirschman, A. (1958) The Strategy of Economic Development, New Haven: Yale University Press. (1968) The Political Economy of Import-Substituting Industrialization in Latin America, The Quarterly Journal of Economics, 82(1):1-32.

Instituto Brasileiro de Geografia e Estatística. (2019a). Pesquisa Industrial Anual - PIA [database]. Retrieved from https://sidra.ibge.gov.br/pesquisa/pia-empresa/quadros/brasil/2017.

Instituto Brasileiro de Geografia e Estatística. (2019b). Pesquisa Anual de Serviços - PAS [database]. Retrieved from https://sidra.ibge.gov.br/pesquisa/pas/tabelas.

Instituto Brasileiro de Geografia e Estatística. (2019c). Pesquisa Anual de Comércio - PAC [database]. Retrieved from https://sidra.ibge.gov.br/pesquisa/pac/quadros/brasil/2017.

Instituto Brasileiro de Geografia e Estatística. (2019d). Pesquisa da Indústria da Construção - PAIC [database]. Retrieved from https://sidra.ibge.gov.br/pesquisa/paic/quadros/brasil/2017.

Klitgaard, T. (1999). Exchange rates and profit margins: the case of Japanese exporters. Economic Policy Review, 5(1).

Lavoie, M. (2002). The Kaleckian growth model with target return pricing and conflict inflation. In M. (2002). Setterfield (Ed.), The economics of demand-led growth. (2002nd ed., p. 172). Edward Elgar Publishing.

Lima, G. T. (2013). Profit Sharing, Capacity Utilization and Growth in a Post-Keynesian Macromodel. In M. (Ed. ). (2010). Setterfield (Ed.), Handbook of Alternative Theories of Economic Growth (2010th ed., p. 344). https://doi.org/10.4337/9781849805582.00027

Mann, C. L. (1986). Prices, profit margins, and exchange rates. Fed. Res. Bull., 72, 366.

Montiel, P. J., \& Agénor, P. R. (2008). Development macroeconomics. Princeton University Press.

Patel, N., Wang, Z., \& Wei, S. J. (2014). Global value chains and effective exchange rates at the country-sector level (No. w20236). National Bureau of Economic Research.

Rapetti, M. (2016). The Real Exchange Rate and Economic Growth: Some Observations on the Possible Channels. In M. Damill, M. Rapetti, \& G. Rozenwurcel (Eds.), Macroeconomics and Development. https://doi.org/10.7312/dami17508-014

Requena-Silvente, F., \& Walker, J. (2007). The Impact of Exchange Rate Fluctuations on Profit Margins: The UK Car Market, 1971-2002. Journal of Applied Economics, 10(1), 213-235.

Rodrik, D. (2008). The real exchange rate and economic growth. Brookings Papers on Economic Activity, 2008(2), 365-412.

Timmer, M. P., Dietzenbacher, E., Los, B., Stehrer, R. and de Vries, G. J. (2015), An Illustrated User Guide to the World Input-Output Database: the Case of Global Automotive Production, Review of International Economics, 23, 575-605. 


\section{APPENDIX A}

The following definitions are necessary:

$R T=$ Gross revenue $=Y=$ Gross output

$Y_{\text {int }}=$ Domestic Gross Revenue

$X=$ Export Revenue (in $R \$)$

Rme $=$ Average Revenue

$P_{\text {int }}=$ Price of Final Goods in Domestic Market

$Q_{\text {int }}=$ Quantity of goods sold in Domestic Market

$P_{\text {exp }}=$ Price of Final Goods in Foreign Market (in US\$)

$E=$ Nominal Exchange Rate

$Q_{\text {exp }}=$ Quantity of goods sold in Foreign Market

$Q_{v}=$ Total quantity of sold goods

$Q_{p}=$ Total quantity of produced goods

$Y=$ Value of Output $=R T+\Delta S$

$\Delta S=$ Stock Variation

$C T=$ Total Cost

$\mathrm{CMe}=$ Average Cost

$C_{i m p}=$ Imported Input cost (in $\left.R \$\right)$

$P_{\text {imp }}=$ Imported Input price (in US\$)

$Q_{\text {imp }}=$ Quantity of imported inputs

$C_{\text {nac }}=$ Domestic Input cost

$P_{\text {nac }}=$ Domestic Input price

$Q_{n a c}=$ Quantity of domestic inputs

$W=$ Total Wages $($ labor cost $)$

$N=$ Number of workers

$W_{m}=$ Average WageW $_{m}=$ Average Wage $=\frac{W}{N}$ 


$$
\begin{aligned}
& \lambda=\frac{Q_{p}}{N}=\text { Labor Productivity } \\
& \frac{W_{m}}{\lambda}=\frac{\frac{W}{N}}{\frac{Q_{p}}{N}}=\frac{W}{Q_{p}}=\text { Nominal Unit Labor Cost }(U L C) \\
& \text { Nominal Unit Labor Cost }(U L C) \\
& L=\text { Total profit } \\
& K=\text { Capital Stock } \\
& \pi=\text { Profit Rate } \\
& m=\text { Profit Margin }
\end{aligned}
$$

The cost and revenue equations are:

$$
\begin{aligned}
& C T=W_{m} \cdot N+P_{i m p} \cdot E \cdot Q_{i m p}+P_{n a c} \cdot Q_{n a c} \\
& R T=Y_{i n t}+X \\
& R T=P_{i n t} \cdot Q_{i n t}+P_{\text {exp }} \cdot E \cdot Q_{\text {exp }} \\
& C M e=\frac{\left(W_{m} \cdot N\right)}{Q_{p}}+\frac{\left(P_{i m p} \cdot E \cdot Q_{i m p}\right)}{Q_{p}}+\frac{P_{n a c} \cdot Q_{n a c}}{Q_{p}} \\
& R m e=\frac{\left(P_{\text {int }} \cdot Q_{i n t}\right)}{Q_{v}}+\frac{\left(P_{\text {exp }} \cdot E \cdot Q_{\text {exp }}\right)}{Q_{v}}
\end{aligned}
$$

considering that:

$\frac{Q_{i m p}}{Q_{P}}=\alpha=$ imported input coefficent

$\frac{Q_{n a c}}{Q_{p}}=1-\alpha=$ domestic input coefficent

$\frac{Q_{\text {int }}}{Q_{v}}=\beta=$ domestic revenue coefficent

$\frac{Q_{\text {exp }}}{Q_{v}}=1-\beta=$ export coefficent 
since,

$$
\begin{aligned}
& Q_{v}=Q_{i n t}+Q_{\text {exp }} \\
& Q_{p}=Q_{i m p}+Q_{n a c}
\end{aligned}
$$

and, to simplify:

$Q_{p}=Q_{v}$

It is possible to redefine the average cost and revenue equations and to determine the profit margin and rate equations:

$$
\begin{aligned}
& C M e=\frac{W_{m}}{\lambda}+\alpha \cdot P_{\text {imp }} \cdot E+(1-\alpha) \cdot P_{n a c}, \text { or } \\
& C M e=C U T+\alpha \cdot P_{\text {imp }} \cdot E+(1-\alpha) \cdot P_{n a c} \\
& R M e=\beta \cdot P_{\text {int }}+(1-\beta) \cdot P_{\text {exp }} \cdot E \\
& \frac{L M e}{R M e}=\left[\frac{\beta \cdot P_{\text {int }}+(1-\beta) \cdot P_{\text {exp }} \cdot E}{\beta \cdot P_{\text {int }}+(1-\beta) \cdot P_{\text {exp }} \cdot E}\right](-)\left[\frac{U L C+\alpha \cdot P_{\text {imp }} \cdot E+(1-\alpha) \cdot P_{n a c}}{\beta \cdot P_{\text {int }}+(1-\beta) \cdot P_{\text {exp }} \cdot E}\right] \\
& m=1-\left[\frac{U L C+\alpha \cdot P_{\text {imp }} \cdot E+(1-\alpha) \cdot P_{n a c}}{\beta \cdot P_{\text {int }}+(1-\beta) \cdot P_{\text {exp }} \cdot E}\right] \\
& \pi=m \cdot \frac{Y-\Delta S}{K}, \text { since we consider } Q_{p}=Q_{v}, \Delta S=0, \text { so } \pi=m \cdot \frac{Y}{K} \\
& \pi=1-\left[\frac{U L C+\alpha \cdot P_{\text {imp }} \cdot E+(1-\alpha) \cdot P_{\text {nac }}}{\beta \cdot P_{\text {int }}+(1-\beta) \cdot P_{\text {exp }} \cdot E}\right] \cdot \frac{Y}{K}
\end{aligned}
$$

